USAWC STRATEGY RESEARCH PROJECT

\title{
IS THE ALL-VOLUNTEER FORCE STILL VIABLE?
}

\author{
by \\ Colonel Robert D. Carlson \\ United States Army Reserve \\ Professor James Kievit \\ Project Adviser
}

This SRP is submitted in partial fulfillment of the requirements of the Master of Strategic Studies Degree.
The U.S. Army War College is accredited by the Commission on Higher Education of the Middle States
Association of Colleges and Schools, 3624 Market Street, Philadelphia, PA 19104, (215) 662-5606. The
Commission on Higher Education is an institutional accrediting agency recognized by the U.S. Secretary
of Education and the Council for Higher Education Accreditation.

The views expressed in this student academic research paper are those of the author and do not reflect the official policy or position of the Department of the Army, Department of Defense, or the U.S. Government.

\author{
U.S. Army War College \\ CARLISLE BARRACKS, PENNSYLVANIA 17013
}




\section{Report Documentation Page}

Form Approved

OMB No. 0704-0188

Public reporting burden for the collection of information is estimated to average 1 hour per response, including the time for reviewing instructions, searching existing data sources, gathering and maintaining the data needed, and completing and reviewing the collection of information. Send comments regarding this burden estimate or any other aspect of this collection of information,

including suggestions for reducing this burden, to Washington Headquarters Services, Directorate for Information Operations and Reports, 1215 Jefferson Davis Highway, Suite 1204, Arlington

VA 22202-4302. Respondents should be aware that notwithstanding any other provision of law, no person shall be subject to a penalty for failing to comply with a collection of information if it

does not display a currently valid OMB control number.

\begin{tabular}{|c|c|c|}
\hline $\begin{array}{l}\text { 1. REPORT DATE } \\
\mathbf{1 5} \text { MAR } 2006\end{array}$ & 2. REPORT TYPE & $\begin{array}{l}\text { 3. DATES COVERED } \\
\mathbf{0 0 - 0 0 - 2 0 0 5} \text { to 00-00-2006 }\end{array}$ \\
\hline \multirow{3}{*}{\multicolumn{2}{|c|}{$\begin{array}{l}\text { 4. TITLE AND SUBTITLE } \\
\text { Is the All-Volunteer Force Still Viable? }\end{array}$}} & 5a. CONTRACT NUMBER \\
\hline & & 5b. GRANT NUMBER \\
\hline & & 5c. PROGRAM ELEMENT NUMBER \\
\hline \multirow{3}{*}{\multicolumn{2}{|c|}{$\begin{array}{l}\text { 6. AUTHOR(S) } \\
\text { Robert Carlson }\end{array}$}} & 5d. PROJECT NUMBER \\
\hline & & 5e. TASK NUMBER \\
\hline & & 5f. WORK UNIT NUMBER \\
\hline \multicolumn{2}{|c|}{$\begin{array}{l}\text { 7. PERFORMING ORGANIZATION NAME(S) AND ADDRESS(ES) } \\
\text { U.S. Army War College,Carlisle Barracks,Carlisle,PA,17013-5050 }\end{array}$} & $\begin{array}{l}\text { 8. PERFORMING ORGANIZATION } \\
\text { REPORT NUMBER }\end{array}$ \\
\hline \multirow{2}{*}{\multicolumn{2}{|c|}{ 9. SPONSORING/MONITORING AGENCY NAME(S) AND ADDRESS(ES) }} & 10. SPONSOR/MONITOR'S ACRONYM(S) \\
\hline & & $\begin{array}{l}\text { 11. SPONSOR/MONITOR'S REPORT } \\
\text { NUMBER(S) }\end{array}$ \\
\hline
\end{tabular}

12. DISTRIBUTION/AVAILABILITY STATEMENT

Approved for public release; distribution unlimited

13. SUPPLEMENTARY NOTES

14. ABSTRACT

See attached.

15. SUBJECT TERMS

16. SECURITY CLASSIFICATION OF:

a. REPORT

unclassified b. ABSTRACT

unclassified c. THIS PAGE

unclassified
17. LIMITATION OF ABSTRACT

\begin{tabular}{|c|l|}
\hline $\begin{array}{c}\text { 18. NUMBER } \\
\text { OF PAGES }\end{array}$ & 19a. NAME OF \\
$\mathbf{2 4}$ & RESPONSIBLE PERSON \\
& \\
\hline
\end{tabular}




\section{ABSTRACT}

AUTHOR: $\quad$ Colonel Robert D. Carlson

TITLE: Is the All-Volunteer Force Still Viable?

FORMAT: $\quad$ Strategy Research Project

DATE: 26 January 2006 WORD COUNT: 7,008 PAGES: 23

KEY TERMS: $\quad$ Force Structure, Operational Requirements, Deployment Ratio, Recruiting, Retention, Force Stress, Mitigative Actions

CLASSIFICATION: Unclassified

The nation faces significant challenges in using an all-volunteer force (AVF) to execute sustained worldwide high-tempo military operations (OPTEMPO) as well as provide for homeland defense. Available evidence appears to support a thesis that extensive use of military forces in a variety of roles and in a continuous cycle of deployments has considerably strained the United States Army manpower system. This study looks at the Army's force structure and examines stress associated with using an AVF to perform the military's numerous operational requirements. It concludes that the AVF concept remains viable only if the Army successfully implements a combination of long-term, more permanent mitigative measures to address force stress resulting from OPTEMPO. 



\section{IS THE ALL-VOLUNTEER FORCE STILL VIABLE?}

The United States (U.S.) military is currently facing demands that are more widespread, prolonged, and intensive than at any time since the Vietnam War. Since the attacks on the World Trade Center in New York City and the Pentagon in Washington, D.C. by terrorists on September 11, 2001 (hereafter referred to as ' $9 / 11$ '), the nation has increasingly encountered significant challenges in using an all-volunteer force (AVF) to execute sustained worldwide hightempo military operations (OPTEMPO) as well as provide for homeland defense. Performing large-scale stability and security-assistance operations in Iraq and Afghanistan, maintaining a substantial force presence in Europe and northeast Asia, conducting ongoing homeland defense missions in the U.S., and executing various peacekeeping operations around the world are straining the military's capability to carry out the Bush Administration's stated geostrategic goals. These goals include: striking preemptively against foreign states or entities that threaten America by harboring terrorists or developing weapons of mass destruction; deterring North Korea from invading South Korea; stabilizing the Middle East region and other fragile and failed nation-states worldwide; and eradicating al Qaeda and other terrorist groups by prosecuting the global war on terrorism (GWOT). ${ }^{1}$ The extensive use of military forces in a variety of roles results in a continuous cycle of deployments that places considerable strain on the Army manpower resource system - ultimately affecting the recruiting and retention of high-quality soldiers. This study looks at the Army's force structure and examines stress associated with using an AVF to perform the military's numerous operational requirements. It concludes that the AVF concept remains viable only if the Army successfully implements a combination of longterm, more permanent mitigative measures to address force stress resulting from OPTEMPO.

\section{History of the AVF and Conscription}

The concept of an AVF in U.S. military annals has a rich and distinct lineage dating back to the American Continental Army during the eighteenth century. Historically, the military has primarily relied on volunteer soldiers to fill its ranks in defending the homeland and prosecuting wars with the notable exceptions of the Civil War during its latter years, World Wars I \& II, and throughout the Cold War-era until 1973. It was at this point during the Nixon Administration that the highly controversial and unpopular draft was terminated, and Congress enacted the current AVF.

The first conscription act was passed in 1863 during the Civil War. However, the act contained two questionable exemption provisions: a set fee could be paid by a potential recruit to avoid a specific draft notice or an individual could find and pay a volunteer replacement for 
three years of service. The result of this law created an incendiary mix of individual

inducements and unanticipated social outcomes, including virulent anti-conscription riots among the urban working class. Historian James McPherson notes that the slogan "a rich man's fight, but a poor man's war" had a powerful impact among the impoverished working class who formed the mainstay of conscripted armies. Additionally, there appeared something unprincipled about the idea that money could be bartered for civic duty. Consequently, this provision of the law earned a dubious reputation after the Civil War and Congress was careful not to repeat its mistakes when developing the World War I-era Selective Service Act. ${ }^{3}$

During periods when the nation has been immersed in total war, such as World Wars I \& II, compulsory military service was mostly universally applied and equitably administered by the government, and was viewed much more favorably by the public. However, during the Cold War period when the U.S. became involved in limited wars against North Korea and later North Vietnam, conscription became increasingly contentious. Particularly in the case of the Vietnam War, public antipathy for the draft reached its pinnacle during the late 1960s and early 1970s due to the immense unpopularity of the war. According to military research analyst William A. Galston, "The Vietnam-era military draft was widely regarded as arbitrary and unfair, and it was held responsible for dissension within the military as well as the wider society." ${ }^{4}$ Largely due to the nation's viscerally negative reaction to the Vietnam draft, most leaders within today's military and Congress are opposed to reinstituting mandatory military service as a way to meet the Army's manpower needs. There are additional concerns of whether conscripted forces can adequately meet the rigorous mental and physical challenges facing current AVF soldiers in an increasingly technical military that is engaging in irregular warfare in a highly fluid, complex battle environment.

\section{Force Transition Requirements}

As the Army transitions into the twenty-first century from a large conventionally-based force to that of a mobile expeditionary force, it is being asked to undertake a variety of additional worldwide missions. This is despite a significant drawdown in manpower and force structure since the Cold War. The end-strength of the Army active-duty force fluctuated from a low of 858.6 thousand to a high of 1.59 million military personnel between the Korean and Vietnam Wars. In comparison, from the end of the Vietnam draft in 1973 to 1999, the Army's total numbers steadily decreased from 800.9 thousand to a modern historic low of 479.4 thousand active-duty service members. ${ }^{5}$ Similarly, the force structure has decreased from 18 to 10 activeduty divisions. ${ }^{6}$ However, as the size of the force contracted, the expectation was that the 
military's requirements would correspondingly decrease. This has not materialized - to the contrary, the OPTEMPO has significantly increased since post-9/11 and the recent advent of the GWOT. As a result, the military - in particular the Army - is stretched thin as it struggles to meet its mission requirements in various locations throughout the world.

Under the most recent Department of Defense (DOD) war planning guidance, the current sizing requirements for the military is based on the "1-4-2-1" operational construct. Specifically, this guidance requires that the military be able to perform the following missions simultaneously: defend the continental U.S. and its territories against external attack ("1"); deter aggression and coercion in four critical regions: northeast Asia, the east Asian littoral, the Middle East and southwest Asia, and Europe ("4"); swiftly deter andlor defeat the efforts of adversaries in two overlapping wars ("2") while preserving the option to exploit decisive victory in one of these conflicts ("1"); and conduct a limited number of lesser contingency operations as required. ${ }^{7}$ In early 2005 the Army's Chief of Staff, General Peter Schoomaker, further defined DOD's planning requirement: "to be able to deploy and sustain 20 brigade combat teams." ${ }^{8}$ This 20 brigade requirement includes conducting recurring rotational deployments to places such as Iraq and Afghanistan, forward stationing of brigades in northeast Asia and Europe, and maintaining several brigades in reserve for other contingencies such as the Balkans. ${ }^{9}$ Furthermore, there is an additional concept referred to as the "10-30-30" planning metric that the military must conform to operationally. This idea calls for U.S. forces to be capable of initiating operations against a major regional adversary within ten days ("10"), of defeating this enemy within 30 days ("30"), and 'resetting' itself to conduct additional operations within the following 30 days ("30"). ${ }^{10}$ The result of these DOD operational requirements has placed a significant strain on the Army's manpower resource system.

As the Army continues to transform from a conventional to modular-based force, significant combat unit restructuring is occurring across the military. The Army is reconfiguring its ten divisions to make the brigade its primary unit of organization for conducting combat operations. ${ }^{11}$ The initial deployments to Afghanistan and Iraq came from an active Army force that was comprised of 33 such brigades. However, during 2004 the Army began to transform its overall combat structure to make it more modular and flexible to meet the emerging challenges of conducting asymmetrical warfare. This transformation is expected to be complete for the entire active and reserve Army forces by 2010. The intent is to reduce the size of the divisional elements and create smaller, self-sustaining brigade combat teams (BCTs) that can be taskorganized to meet the Army's broad mission base. Current DOD force structure plans call for creating at least 43 active-duty transformed BCTs in place of the 33 original brigades that 
previously existed, with the potential of expanding further to 48 BCTs. ${ }^{12}$ Under this new concept, each BCT will be a stand-alone tactical force of between 3,500 and 4,000 soldiers. Ultimately the Army plans to resource 12 expeditionary packages from the total transformed force to provide a continuous and efficient flow of BCTs to the combatant commanders while providing predictable unit deployment schedules for soldiers and their families. ${ }^{13}$

Another important factor to consider as the Army undergoes its transformation is the prevailing force rotation policy in effect for deployments. This specifically refers to the mobilization rate that a unit can expect to experience in today's environment, simply expressed in terms of a deployment ratio. Although there is significant uncertainty about the pace of deployments that would be considered unsustainable over the long term, the Congressional Budget Office (CBO) has identified certain benchmarks that Congress and DOD have considered acceptable. Mobilization tempo guidelines contained in Public Law 106-945 (the Floyd D. Spence National Defense Authorization Act for Fiscal Year 2003) suggest that a deployment ratio range between 3.2:1 and 4:1 for active-component units is feasible and sustainable. ${ }^{14}$ Based on a 12 month deployment timeframe, this means it requires between 3.2 and 4 units to sustain a single mobilized unit when considering the recovery, training, and preparation time in garrison for redeploying forces during the normal readiness cycle. The goal of attaining this deployment ratio was further supported by General Richard Cody, Vice-Chief of Staff, U.S. Army, at a hearing of the Subcommittee on Military Personnel, House Committee on Armed Services, on February 2, 2005. However, since this period, the Army has formally committed to somewhat higher rotation rates for deploying forces, whereby many active-duty component units have only one year between mobilizations and are effectively sustaining a deployment ratio of $2: 1 .^{15}$ Likewise, DOD recently established a benchmark of mobilizing reserve component units one out of every six years, or a deployment ratio of 6:1. Nevertheless, the $\mathrm{CBO}$ has identified some incongruities with DOD's rotation rate figures because of the need to account for longer pre- and post-deployment activities, and suggests that a sustained deployment ratio between 7.5:1 and 9:1 is more realistic for the reserve forces. ${ }^{16}$ Irrespective of these differences, the current rotation rate of military forces is a growing concern for Congressional and DOD leaders.

\section{Recruiting and Retention}

Since reaching a personnel strength-level nadir in 1999, the Army has begun to slowly increase its active-duty component end-strength. According to the Pentagon G1 staff, the Army was authorized a 502.4 thousand active-duty end-strength for $2005 .{ }^{17}$ Moreover, Congress has 
granted DOD the authority to temporarily augment this figure by up to 30 thousand additional soldiers over the next several years as the Army is attempting to maintain its current OPTEMPO. ${ }^{18}$ However, partially because of this authorized increase to the active-duty manpower ceiling, the Army is experiencing certain problems in the areas of recruiting and retention.

Each year DOD establishes different active and reserve component military personnel recruiting goals based on the needs of the Army. There are both 'quantity' and 'quality' aspects to these goals. Quantity goals are measured strictly in terms of meeting pre-established numerical personnel levels, whereas quality goals are based on two factors: graduation rates from high school (i.e., at least 90 percent of the recruits must have a high school diploma or GED equivalent) and attaining at least a certain minimum score on the Armed Forces Qualification Test (AFQT) (i.e., at least 60 percent must score above average). ${ }^{19}$

For non-prior service enlisted personnel in fiscal years (FYs) 2000 through 2003, both the active-duty and reserve components of the Army met or exceeded their respective quantity recruiting goals with the exception of the National Guard in FY2003, whose aggregate total was 82 percent. $^{20}$ For FY2004 and FY2005, the quantity goals were the following: for the active-duty force, 77 thousand and 80 thousand, respectively; for the National Guard, 56 thousand and 63 thousand, respectively; and for the Army Reserve, 32.3 thousand and 28.5 thousand, respectively. In FY2004 the active-duty and Army Reserve components met their numerical recruiting quotas, while the National Guard reached only 87 percent of its total goal. ${ }^{21}$ Furthermore, in FY2005 all three components missed their quantity recruiting goals. For the active-duty component, new accessions (i.e., the number of individuals who have actually begun their military service as distinguished from those who are in a delayed entry program) accounted for only 92 percent of its numerical goal. Similarly, accessions for the Army Reserve and National Guard were 84 percent and 80 percent, respectively, of total numerical quotas. ${ }^{22}$ Based on aggregate recruiting numbers, the National Guard has failed to meet its numerical quotas since FY2002. ${ }^{23}$

With respect to quality recruiting goals, both the active-duty and Army Reserve components were able to meet their FY2004 and FY2005 quotas of 90 percent new accessions having high school diplomas or GED equivalents, and at least 60 percent scoring above average on the AFQT. Nonetheless, the National Guard missed this quality goal in both of these years with only 84 percent of its new recruits having high school diplomas and 57 percent scoring above average on the AFQT. ${ }^{24}$ Although the Army was able to meet its numerical recruiting goals during the first two months of FY2006, this was accomplished by accepting 12 
percent of its new accessions from the lowest scoring pool, known as Category IV recruits. According to DOD rules, the Army can admit no more than four percent Category IV recruits annually. ${ }^{25}$ This means in future months the Army will have to accept fewer Category IV recruits than the allowable standard in order to be in compliance with DOD guidance by year's end.

There are some reasons for concern when looking closer at the Army's recruiting numbers over the last several years. For instance, the Army met its active-duty accession quantity goal in FY2004 in part by drawing heavily from its Delayed Entry Program (DEP), the pool of new recruits who have signed a contract to join the military at a future date (i.e., up to one year in advance), but have yet to be sent to basic training. In general, the Army prefers to have at least 35 percent of the coming year's accession goal enrolled in the DEP in order to efficiently manage the flow of new recruits through its training bases. However, by the end of FY2004 the Army's DEP was reduced to about 18 percent of its FY2005 recruiting goal. This decline in the DEP pool is partially explained by Congress' decision in early 2004 to increase the size of the Army's active-duty force, thereby creating a need to send more recruits to basic training than had previously been planned. Also contributing to this problem was that the Army missed its FY2004 goal for new recruit contracts by 15 percent. ${ }^{26}$ The combination of an increased manpower ceiling, a declining DEP pool, and several missed accession quantity and quality goals over the last several years among the active-duty, Army Reserve, and National Guard components does not augur well for the Army as it struggles to fill its ranks with the quantity and quality of new recruits needed to sustain the current OPTEMPO.

There appear to be several probable causes contributing to the Army's recruiting shortfalls. During times when the national economy is solidly performing, it becomes more difficult for the military to recruit highly desirable prospects. According to the Bureau of Labor Statistics, recent unemployment trends have been steadily decreasing, falling from a high of 6.3 percent in June 2003 to 4.9 percent in December 2005. ${ }^{27}$ The military is also competing with post-secondary academic institutions for the same pool of potential candidates. Based on numbers from the Department of Education, over the past 25 years the proportion of high school graduates going directly to college has increased from approximately 50 to 67 percent. ${ }^{28}$

Aside from these general economic and social factors that impact the military's ability to recruit, there seem to be some acute reasons further undercutting the Army's endeavors. Foremost among these reasons is the protracted Iraq conflict, where the Army has borne the bulk of the effort in this war. Recent DOD sponsored surveys indicate that certain segments of the adult population - especially women and African Americans - are less likely to recommend military service to young people since the onset of war in Iraq. The effect of this negative 
attitude towards the Army by this group of adults has resulted in far fewer African-American prospects for recruiters. In FY2000, 23.5 percent of all Army recruits were African American by contrast today, African Americans comprised only about 14 percent of accessions in FY2005. ${ }^{29}$ Likewise, adults who are considered youth 'influencers' (e.g., parents, coaches, teachers, and mentors) are also discouraging against enlisting in the Army, which is presenting difficulties for recruiters who are targeting high school seniors below the age of 18 and require parental consent to join the military. Another factor affecting recruiting is the Army's ongoing effort to expand the active-duty force. This puts active-duty recruiters into more vigorous competition with the Army Reserve and National Guard for some of the same potential recruits. Moreover, comparatively high mobilization rates in the Army Reserve and National Guard in recent years may also be adversely impacting the Army's recruiting efforts. In general, personnel departing active-duty service become a significant source of recruits for the Army's reserve components. However, with the current OPTEMPO increasing deployments of the Army Reserves and National Guard, many individuals are opting out of the military entirely after completing active-duty service. This is particularly evident in the National Guard, where the flow of active-duty enlisted soldiers to the guard decreased by over 50 percent from FY2002 to FY2004. ${ }^{30}$

Preliminary data appear to indicate less concern about retention rates in the Army despite the post-9/11 OPTEMPO for the military. The active-duty component has met its percentage of enlisted aggregate retention goals over the past five years in each of the three categories that it tracks this data. These categories include: initial term, consisting of first term enlistments regardless of length; mid-career, comprised of second or subsequent term enlistments with up to ten years of service; and career, composed of second or subsequent term enlistments with ten or more years of service. In contrast, the reserve component tracks its enlisted aggregate retention goals through attrition rates, measured as a ratio of individuals departing the military in a given year compared to the total authorized personnel level for that particular service. The Army Reserve and National Guard both have pre-established attrition goals that have been constant since FY2000, which represent the maximum percentage of the force that a component can lose each year and still meet authorized manpower levels. The National Guard exceeded its attrition ceiling of 19.5 percent in FY2001 and FY2002 by approximately one percent or less, while the Army Reserve surpassed its attrition upper limit in FY2000 by less than one percent. ${ }^{31}$

Although these mostly positive retention figures would appear counter-intuitive based on the military's OPTEMPO since 9/11, there were a number of studies conducted in the late 1990s 
indicating that deployments may enhance retention, possibly by providing soldiers with a sense of accomplishment. Nonetheless, these studies also point out that after crossing a particular threshold, this positive effect diminishes or becomes negative. It should further be noted that these studies dealt with retention behavior during the 1990s, when deployments were more infrequent, of shorter duration, and generally under less hostile conditions. ${ }^{32}$ The Army's controversial use of the 'stop loss' provision to prevent personnel from departing the military when a unit is deployed or about to be mobilized may also have negative long-term implications. According to the Government Accounting Office, "Congress has expressed concern that the use of stop loss to meet overall personnel requirements may have a negative impact on recruiting and retention and the public's perception of the military." ${ }^{33}$

There are some additional indicators that could raise concern about future retention rates. For instance, based on recent DOD sponsored survey results conducted to determine the intentions of soldiers wanting to remain in the Army beyond their current commitment, the trends were negative. Between March 2003 and August 2004 the 'retention intention' decreased from 59 percent to 52 percent for the active-duty force. A similar survey was conducted for the reserve component between May 2003 and November 2004, where the retention intention dropped from 70 percent to 58 percent among respondents in the National Guard and declined from 69 percent to 57 percent among those in the Army Reserve. ${ }^{34}$ Furthermore, the Army Reserve has had to involuntarily recall members of its Individual Ready Reserve (IRR) to fill personnel shortfalls in active-duty, reserve, and guard units in response to difficulties with recruiting and retention. Approximately 7,000 soldiers have been mobilized from the IRR since 2002, of which over 4,000 were still on active duty as of August $2005 .^{35}$

According to a recent study conducted by the Walter Reed Army Institute of Research (WRAIR) on the impact of OPTEMPO on turnover intentions of Army personnel, the results varied depending on individual circumstances. The intrinsic dichotomy of OPTEMPO effects on different soldiers is complex in that it contributes both to job satisfaction and to personal strain. Factors that played significantly into the decision process of whether to remain in the Army or leave included the OPTEMPO level, personal expectations, family situation, and individual attitudes toward such experiences. ${ }^{36}$ WRAIR posits an intriguing supposition about gauging the future career intentions of military personnel when considering OPTEMPO based on the 'equity theory.' In essence, this theory proposes that the balance between what employees invest and receive from an organization impacts their relationship with the company, ultimately affecting their decision to stay or depart. One considerable investment in the Army by the soldier is personal time. If deployments become too long or frequent, the soldier may end up leaving the 
military because of a perceived imbalance between what is being sacrificed by the individual (e.g., time away from home, hazardous duty, arduous conditions, etc.) and what is being offered by the Army in return (e.g., incentive pay, career progression, etc.). Another variable to consider is the stimulation provided by the OPTEMPO environment and whether the individual derives self-satisfaction from performing such duty. Thus, the expectation is when OPTEMPO is composed of duty that is likely to produce external work-related rewards in terms of monetary incentives, career advancement, schooling, choice assignments, personal stimulation, etc., there is apt to be a correlation with reduced turnover. Conversely, if OPTEMPO is defined by work that results in few external rewards and only equates to protracted and frequent deployments, such measures are expected to result in increased turnover. ${ }^{37}$ The key is to establish an equitable balance between the demands of the Army in this OPTEMPO environment and the needs of the individual military member to create desirable long-term conditions for mission success and service retention.

\section{Force Stress and Mitigative Actions}

It is becoming readily apparent that the current OPTEMPO of the military is placing significant stress on the U.S. armed forces. The U.S. military is located in approximately 130 countries worldwide performing a variety of missions. As of January 2005, nearly 350 thousand service members were serving abroad, with the Army comprising the majority of these forces. ${ }^{38}$ Army forces makeup over 123 thousand of the 199 thousand total U.S. military presently deployed to the Iraq Theater. ${ }^{39}$ The resulting OPTEMPO strain is particularly evident on the Army whose forces are stretched thin as it shoulders the preponderance of the load in the GWOT and other global force presence missions. Recent CBO figures show that the activeduty components of the Army and Marine Corps combined have 41 BCTs and the reserve components possess an additional 39 BCTs. Absent any other international commitments, these forces would be able to sustain about 19 BCTs deployed overseas and still remain within acceptable Congressional and DOD deployment ratio benchmarks discussed previously. However, the current combat force requirements in support of Operation Enduring Freedom (OEF) in Afghanistan and Operation Iraqi Freedom (OIF) in Iraq alone range between 18 and 20 BCTs. Furthermore, U.S. commitments of providing ground forces in northeast Asia, peacekeeping missions in Kosovo and the Sinai Peninsula, and fulfilling other worldwide military operational requirements necessitate about four additional deployed BCTs. ${ }^{40}$ Based on these figures, it is reasonable to conclude that the U.S. military - and particularly the Army - can not sustain the current OPTEMPO without significantly reducing its stated deployment ratio goals 
(i.e., resulting in an increased number of deployment rotations per unit). A prolonged

OPTEMPO could have major repercussions for the Army as it relies on strong retention rates and a steady influx of recruits to fill the ranks of its AVF.

There are several temporary, short-term mitigative actions and also more permanent, long-term measures available to the Army as it continues functioning in an OPTEMPO environment. Each of these options has inherent risks and costs associated with it. In certain instances, DOD is already implementing some of these actions. Notwithstanding these efforts, no near-term option(s) is likely to provide the lasting relief sought by the Army to align its operational requirements with its force structure and rotation base. However, the overall force stress associated with OPTEMPO should decline as the military transitions from more temporary to permanent solutions.

One short-term option already being exercised by the Army involves increasing unit deployment rates and durations. Individual soldiers and BCTs are being deployed more often and for longer periods of time to meet various mission requirements. Although this does nothing to address the force stress issue, it does provide the Army with an interim solution to meet its operational needs. The Rand Corporation recently completed an analysis involving the effects of time away from home on soldiers' quality of life derived from data collected on overseas deployments, hardship assignments (i.e., unaccompanied tours of duty to places such as Korea, etc.), and field training. Based on current worldwide force requirements for BCTs previously noted, active-duty soldiers with certain combat military occupational specialties (MOSs) could conceivably expect to spend over 47 percent of their time away from home over the course of a career. For reserve component soldiers with the same combat MOSs, using a weighted average (i.e., consisting of time expended on drill days, annual training, and mobilizations), these service members could expect to be away from home over 21 percent of the time during their career. ${ }^{41}$ In either case this poses a significant burden on the soldier when current OPTEMPO conditions are extrapolated over an extended period of time. As earlier mentioned in the recent WRAIR analysis and prior studies conducted during the 1990s, soldier retention is adversely affected when certain mobilization thresholds are exceeded or the perceived time invested in deployments (i.e., to include other related time-away-from-home military activities) outweighs the corresponding benefits. This may also inhibit recruiting efforts if prospective enlistees are made aware of these high deployment timeframes. To address this problem from a long-term perspective, the Army will need to consider reducing its level of operational missions abroad andlor increasing its manpower ceiling. 
A further temporary measure the Army is employing involves the 'stop loss' and 'stop movement' provisions. These measures help resolve the Army's immediate personnel shortfall issues - especially in critical high-demand/low-density MOSs - by preventing soldiers from leaving units that are deployed or about to be mobilized up to 90 days after they return from deployment. However, the optics of this approach is less than desirable from a public relations standpoint, and may result in longer term morale and recruiting problems. This is particularly true for soldiers who are coming off active duty and would otherwise join one of the reserve components.

Activating soldiers from the IRR is another interim option the Army is using to fill individual vacancies throughout the service. Nevertheless, this method may prove to be less desirable over the long term due to the initial costs associated with activating and training individuals who in many cases have been removed from any type of military service for several years. Recent DOD estimates indicate that only 69 percent of the 5,700 IRR soldiers recalled since the summer of 2004 actually reported for duty; the remainder were either excused from military service for personal or health-related reasons, could not be located, or refused to show up for duty. ${ }^{42}$ Thus, it would be reasonable to conclude that most 'involuntarily' recalled IRR soldiers will resign from the military after fulfilling an initial tour of duty based on personal hardship or other reasons. As in the case of the stop loss provision, either of these options should be used sparingly until the Army can institute a more permanent solution.

Outsourcing is another approach that the Army is increasingly relying on to satisfy its service support needs. On the surface this appears to make sense, especially for those logistical and rear support functions that can be readily filled by civilian contractors while freeing military personnel to perform other critical combat related tasks. The U.S. military and its allies are already utilizing over 20 thousand contractors in southwest Asia, which approximates the total number of coalition forces serving in Iraq. ${ }^{43}$ However, besides the high cost associated with using contractor personnel, there are other issues that may eventually impact troop morale as well as military good order and discipline. For instance, there are clear differences in pay between soldiers and contract workers (e.g., in some cases contractors make three or four times the salary of a soldier performing commensurate work). Contractors do not fall under the Uniform Code of Military Justice and therefore are often held to a lower standard of conduct than soldiers. Furthermore, contractors generally have a better quality of life in the field (i.e., more amenities and less arduous working conditions) and enjoy more personal freedom than their military counterparts. Of greater concern is when contractor personnel are used in security roles. Specifically, there are issues regarding sharing intelligence information with, and 
providing protection to, contractors; enforcing rules of engagement with security personnel; and differentiating between noncombatants and contractors in the war zone. ${ }^{44}$ It remains unclear whether the benefit of using contract workers exceeds the associated cost and risks involved in order to meet the Army's wartime needs. At a minimum, contractors should be prohibited from performing combat or combat security-related functions in the war zone; but if required, then they should be used sparingly and limited to rear-area support operations.

Other short-term mitigation actions include the U.S. applying more diplomatic pressure on its North Atlantic Treaty Organization (NATO) allies and the United Nations to provide additional military relief forces in support of OEF, OIF, and the GWOT. Although this would appear to be the ideal solution, it has proved to be a chimera because of strong political opposition from France and Germany, and the tepid support by other NATO allies due to the vociferous opposition from the majority of European people over the war in Iraq. To entice additional military support, the U.S. should increase the political and economic leverage of certain major allies such as France and Germany by including them in more decision-making processes and reconstruction activities in Iraq and Afghanistan. Moreover, the U.S. can offer additional economic aid or Administration entrée to other more needy countries that would be willing to exchange military support for financial gain or political clout. Access to additional coalition military forces in support of OIF and OEF would provide substantial relief to the beleaguered Army.

Another interim option is to increase the pace of security handoff to indigenous Afghani and Iraqi forces. While this would significantly ease demands on U.S. forces, there are significant risks associated with an accelerated timetable for Afghani and Iraqi security independence. At a minimum, this would require a substantial additional investment in training and equipment to elevate both security forces to an acceptable level of proficiency and professionalism to operate on their own. This training could be conducted primarily by contractors with a small cadre of military personnel providing oversight, thus freeing additional military resources to perform other functions.

There are also more long-term, permanent solutions to the Army's present manpower shortage, some of which are already being implemented. The military is currently downsizing its overseas forces in traditional places such as Western Europe and northeast Asia, as well as reducing the number of peacekeeping and nation-building operations in locations like the Balkans that the Army is involved in worldwide. Nonetheless, as the Army continues to restructure and realign its global mission focus, there is ongoing debate in Congress about the future role of the military and whether it should include peacekeeping and related stability 
operations as part of its core functions. These concerns were heightened by findings in the $9 / 11$ Commission Report which cited Afghanistan - a place where the military has limited peacekeeping and nation-building presence - as becoming a sanctuary for terrorists. ${ }^{45}$ If the Army plans to include these types of non-combat operations as part of its future core mission capability, then serious thought should be given to permanently increase the size of the military force beyond levels already approved by Congress. Although an expensive proposition, it would seem prudent to consider expanding the Army's peacetime force to approximate wartime manpower levels in order to perform the myriad of global mission requirements without further increasing associated force stress. The alternative is to continue reducing the Army's worldwide presence by decreasing or eliminating certain operational missions while leveraging existing manpower through force modernization and internal restructuring.

The Army is continuing its force transformation as it restructures under the modularized BCT concept. According to DOD, the new modular force will increase the number of deployable combat brigades, thus reducing the rate of rotation for Army forces. ${ }^{46}$ Additionally, the Army is implementing other restructuring activities to help mitigate force stress over the long term. One major effort being undertaken is a 'rebalancing' of the Army's force composition to improve its war fighting capacity to meet emerging threats in this new era of warfare. As the Army transitions from its Cold War conventional posture to a more flexible rapid response structure, it is downsizing traditional MOSs such as field artillery and air defense artillery, and converting these positions to more relevant high-demand/low-density jobs like the military police, intelligence, Special Forces, and civil affairs. ${ }^{47}$ This plan ultimately calls for conversion of 125 thousand positions. Another measure being taken to provide OPTEMPO relief is increasing the Army's 'operational force' end-strength (i.e., forces that are categorized as MTOE instead of TDA and other non-line unit statuses) by 40 thousand soldiers by FY2007. According to Army Secretary Francis Harvey, DOD plans to accomplish this through the combination of converting 29 thousand military jobs to civilian positions and reducing the number of service members in transit to training and the schoolhouse by an additional 11 thousand, thus freeing these soldiers to perform more critical missions. ${ }^{48}$ These steps, in conjunction with the Army's efforts to leverage fire support capabilities from its sister services and the exploitation of technology to substitute for manpower in many instances, should result in a substantial increase in available forces being used for deployments. ${ }^{49}$

DOD has been authorized a temporary increase in the Army's manpower ceiling to help deal with existing force stress that is induced by the present OPTEMPO. However, as formerly alluded to, the Army is experiencing difficulties in recruiting, with potentially ominous signs for 
soldier retention. To address these problems, the Army has substantially revised and increased its advertising, recruiting, and enlistment and reenlistment bonus programs. For example, the Army enlarged its overall staff of recruiters by 3,498 from FY2004 to FY2005, representing a 41 percent increase over the previous year. Similarly, the Army has increased its advertising budget and redirected the focus of its recruiting message to reach out to youth 'influencers' previously discussed. The military is also soliciting the support of soldiers returning from OEF and OIF in its Special Recruiter Assistance Program. These soldiers are assisting hometown recruiters with conveying their message about the virtues of service in the Army and helping to gain high school graduate leads and potential enlistments..$^{50}$ For new recruits, legislation is pending to authorize a 100 percent increase - from $\$ 20$ thousand to $\$ 40$ thousand - in enlistment bonuses for certain MOSs, and an additional $\$ 400$ per month while mobilized for those who sign up and then deploy with a unit on the next troop rotation to Afghanistan or Iraq. ${ }^{51}$ Those who serve in Special Operations Forces and other specified critical MOSs are eligible to receive up to $\$ 150$ thousand for reenlisting for an additional six years beyond their 19 year service mark. Likewise, the Army has instituted its Critical Skills Retention Bonus Program for certain MOSs, providing up to $\$ 1,500$ a month for enlisted service members..$^{52}$ In many cases DOD has had to implement this high retention bonus structure to counter lucrative financial incentives being offered by contractors to service members who leave the military and go to work for them as civilians performing similar functions. As earlier noted, this may cause morale problems for soldiers in a deployed environment who view this practice as inequitable (i.e., unequal pay and benefits for equal work). DOD should consider introducing certain hiring restrictions - similar to those placed on Federal civil servants who leave the government and go to work for contractors - on service members who depart the military to perform similar duties for a contractor, especially in a deployed environment. Despite these obstacles, military planners say they are "relatively confident" that these increased measures will help the Army to meet its recruiting and retention goals in FY2006. ${ }^{53}$

The final and most controversial long-term option to address the Army's current personnel shortage is to reinstitute the draft. There are several valid arguments both for and against conscription. Among the most obvious reasons for reinstating the draft is that it provides an immediate and lasting solution to the Army's manpower requirements. Another less tangible albeit supporting reason includes individual civic duty and the need to proportionately distribute the responsibilities of homeland defense and prosecuting the GWOT to a greater share of the American population. Under the AVF system, less than one percent of the U.S. populace (i.e., approximately 2.5 million military personnel from a national population of 295.7 million people ${ }^{54}$ ) 
is serving in the military. In general, from this group minorities tend to be overrepresented in relation to their national demographics. African Americans, for example, account for nearly 25 percent of all enlisted Army soldiers while comprising only 13 percent of the U.S. population. ${ }^{55}$ In some respects the draft would help remedy this disparity by subjecting all eligible youth to mandatory military service - not unlike what is required by many of the world's other countries. Arguments against conscription include its vast unpopularity with the majority of U.S. citizens, including civilian and military leadership. According to a public opinion poll conducted for the Associated Press in June 2005 on this subject, approximately 70 percent of Americans opposed a return to the draft. ${ }^{56}$ Principal research scientist Cindy Williams, from the Massachusetts Institute of Technology, states in her recent study on military service that only between 7.7 and 9 percent of the nation's 2.11 million 18-year-old males would be needed to fill the military's manpower requirements in $2006 .^{57}$ However, this poses the dilemma of who should be required to serve in the military since only a fraction of the eligible youth would be needed. One option would be to require all 18-year-olds to perform some type of mandatory national service, from which a subset of this group would fulfill their obligation through military duty. In order for this to succeed, the government would have to develop an equitable selection process for those required to perform military duty - with no educational or other waivers permitted. Allowing such exemptions harks back to the perceived unfairness and acrimony surrounding previous compulsory military service periods such as the Vietnam-era draft, and only serves to alienate Americans toward the Army. With the nation presently involved in only a limited war as opposed to a total war, and with the national sentiment firmly against conscription, reinstating the draft at this time does not appear to be the most practical solution to resolving the Army's manpower issues.

\section{$\underline{\text { Conclusion }}$}

It is apparent that the nation faces significant challenges in using an AVF to execute a sustained OPTEMPO for the foreseeable future. As the GWOT progresses, the Army is being increasingly tasked with a variety of missions throughout the world. Consequently, Army activeduty and reserve component forces are undergoing considerable stress as a result of continuous deployments. This strain is also impacting the Army's ability to effectively recruit and retain highly qualified personnel. In response, the Army is either examining or has initiated a series of mitigative measures to address its short-term and long-term manpower needs. Outsourcing (under limited conditions), gaining access to additional allied military forces, and expediting the turnover of security operations to indigenous host-nation personnel should yield 
the most benefit in terms of mitigating force stress in the short-term without adversely impacting any of the more permanent solutions underway, such as increased recruiting and retention efforts. Similarly, the Army's ongoing transformation process through force realignment and restructuring, in conjunction with aggressive recruiting and retention actions to increase its endstrength should provide sufficient long-term force stress relief caused by the current OPTEMPO. If these initiatives are successfully implemented, the AVF will remain viable to meet the Army's OPTEMPO requirements as it transitions into the twenty-first century. Conversely, if the Army is unable to adequately employ these permanent measures, then the result will be a force that is stretched to its limit with no reserve capacity. This would detrimentally affect the Army's longterm readiness posture and operational capabilities. Thus, the Army would need to significantly reduce its global mission requirements or assume a higher level of risk - with potential national security implications - due to a degraded force structure. Only effectively implementing these long-term mitigative actions or substantially reducing the current OPTEMPO will result in lasting force stress relief considered necessary by the Army.

\section{Endnotes}

${ }^{1}$ George W. Bush, The National Security Strategy of the United States of America (Washington D.C.: The White House, September 2002), 1-16, passim.

${ }^{2}$ William A. Galston, “Thinking About the Draft," Public Interest 154 (Winter 2004): 68.

${ }^{3}$ lbid., 68-69.

${ }^{4}$ Ibid., 61.

${ }^{5}$ U.S. Department of Defense Directorate of Information Operations and Reports, Washington Headquarters Services, "DOD Active Duty Military Personnel Strength Levels, Fiscal Years 1950-2002," available from http://www.dior.whs.mil/mmid/military/ms8.pdf; Internet; accessed December 2005.

${ }^{6}$ Edward F. Bruner, "Military Forces: What is the Appropriate Size for the United States?" CRS Report for Congress, Order Code RS21754 (Washington, D.C.: The Library of Congress, May 28, 2004), 1.

${ }^{7}$ Donald H. Rumsfeld, The National Defense Strategy of the United States of America (Washington D.C.: The Pentagon, March 2005), 16-17.

${ }^{8}$ Lynn E. Davis et al., "Stretched Thin: Army Forces for Sustained Operations," RAND Corporation, 2005; available from www.rand.org; Internet; accessed October 2005; 6.

${ }^{9}$ lbid. 
${ }^{10}$ Andrew F. Krepinevich, "The Thin Green Line," Center for Strategic and Budgetary Assessments, August 14, 2004 [journal on-line]; available from www.csbaonline.org; Internet; accessed October 2005; 3.

${ }^{11}$ Nina M. Serafino, "Peacekeeping and Related Stability Operations: Issues of U.S. Military Involvement," CRS Issue Brief for Congress, Order Code IB94040 (Washington, D.C.: The Library of Congress, October 27, 2005), 13.

${ }^{12}$ Davis, 7.

${ }^{13}$ Ibid., 8.

${ }^{14}$ U.S. Congressional Budget Office, An Analysis of the U.S. Military's Ability to Sustain an Occupation in Iraq: an Update (Washington, D.C.: U.S. Congressional Budget Office, October 5, 2005), p. 3.

${ }^{15}$ Ibid., 4.

${ }^{16}$ lbid.

${ }^{17}$ Steven E. Galing, COL, Army G-1 Staff, e-mail to Robert D. Carlson, COL, USAWC Student, November 1, 2005.

${ }^{18}$ U.S. House of Representatives, "Conference Report to Accompany H.R. 4200, the Ronald W. Reagan National Defense Authorization Act for Fiscal Year 2005," October 8, 2004; available from www.house.gov/rules/1084200confrept.pdf; Internet; accessed December 2005.

${ }^{19}$ U.S. Government Accountability Office, Military Personnel: DOD Needs Action Plan to Address Enlisted Personnel Recruitment and Retention Challenges, GAO-06-134 (Washington, D.C.: U.S. Government Accountability Office, November 2005), 8, 10.

${ }^{20}$ lbid.

${ }^{21}$ Lawrence Kapp, "Recruiting and Retention: An Overview of FY2004 and FY2005 Results for Active and Reserve Component Enlisted Personnel," CRS Report for Congress, Order Code RL32965 (Washington, D.C.: The Library of Congress, June 30, 2005), 10-11.

${ }^{22}$ U.S. Department of Defense, Office of the Assistant Secretary of Defense, "Fiscal 2005 Active Duty and Reserve Component Enlisted Recruiting from October 1, 2004 - September 30, 2005," October 11, 2005, available from http://www.defenselink.mil/releases/2005/nr200510114881.html; Internet; accessed October 13, 2005.

${ }^{23}$ U.S. Government Accountability Office, 10.

${ }^{24}$ Kapp, 10-11.

${ }^{25}$ Tom Bowman, "Army Met Recruiting Goal in November: But Service Again Accepted a High Percentage of People Who Scored in the Lowest Category on Aptitude Test," Baltimore Sun, December 16, 2005 [newspaper on-line]; available from http://ebird.afis.mil/ebfiles/ e20051216407380.html; Internet; accessed December 16, 2005. 
${ }^{26}$ Kapp, 2.

${ }^{27}$ U.S. Department of Labor, Bureau of Labor Statistics, "Labor Force Status:

Unemployment Rate," Series ID: LNS14000000, available from http://data.bls.gov/PDQ/servlet/ SurveyOutputServlet; Internet; accessed January 9, 2006.

${ }^{28}$ Kapp, 5.

${ }^{29}$ Andrew J. Bacevich, "Who's Bearing the Burden? Iraq \& the Demise of the All-Volunteer Army," Commonwealth 132 (July 15, 2005): 14.

${ }^{30}$ Kapp, 6.

${ }^{31}$ U.S. Government Accountability Office, 10-13.

${ }^{32}$ Kapp, 8-9.

${ }^{33}$ U.S. Government Accountability Office, 16.

${ }^{34}$ Kapp, 9.

${ }^{35}$ U.S. Government Accountability Office, 16-17.

${ }^{36}$ Ann H. Huffman et al., "The Impact of Operations Tempo on Turnover Intentions of Army Personnel," Military Psychology, vol. 17, no. 3, 175-202 (2005): 197.

${ }^{37}$ lbid., 182-183.

${ }^{38}$ Global Security Organization, "Where are the Legions? Global Deployments of U.S. Forces," available from http://www.globalsecurity.org/military/ops/global-deployments.htm; Internet; accessed December 30, 2005.

${ }^{39}$ Linwood B. Carter, "Iraq: Summary of U.S. Forces," CRS Report for Congress, Order Code RL31763 (Washington, D.C.: The Library of Congress, November 28, 2005), 1-2.

${ }^{40}$ U.S. Congressional Budget Office, 4.

${ }^{41}$ Davis, 58-59.

${ }^{42}$ Robert Burns, "Army Reservists Expelled," Associated Press, January 9, 2006 [newswire service on-line]; available from http://www.defenselink.mil; Internet; accessed January 9, 2006.

${ }^{43}$ Krepinevich, 14.

44 Ibid., 14-15.

${ }^{45}$ Serafino, 1.

${ }^{46}$ U.S. Congressional Budget Office, 11.

${ }^{47}$ Krepinevich, 16. 
${ }^{48}$ Jen DiMascio, "Harvey: Army's Modernization Plan to Cost More than $\$ 90$ Billion by 2011," Inside the Army, October 24, 2005.

${ }^{49}$ Krepinevich, 16.

${ }^{50}$ U.S. Government Accountability Office, 29-31.

${ }^{51}$ Joe Galloway, "Broken Army is in need of Repair," Knight Ridder, October 15, 2005.

${ }^{52}$ U.S. Government Accountability Office, 31-32.

${ }^{53}$ Gerry J. Gilmore, "Revamped Army Recruiting System Helps Boost Active-Duty Enlistments," U.S. Department of Defense, American Forces Information Service, October 13, 2005 [news service on-line]; available from http://www.defenselink.mil/news/Oct2005/ 20051012_3024.html; Internet; accessed October 13, 2005.

${ }^{54}$ The Central Intelligence Agency Home Page, available from http://www.cia.gov/cia/ publications/factbook; Internet; accessed January 9, 2006.

${ }^{55}$ David Moniz, "Opportunities, Opposition to Iraq War Cut into Recruiting," USA Today, November 3, 2005 [newspaper on-line]; available from http://www.usatoday.com/news/nation/ 2005-11-03-army-blacks-inside_x.htm; Internet; accessed November 7, 2005.

${ }^{56}$ MSNBC, "Military Draft? Polls Find Americans Opposed," Associated Press, June 24, 2005 [newswire service on-line]; available from http://www.msnbc.msn.com/id/8342995; Internet; accessed January 9, 2006.

${ }^{57}$ Cindy Williams, Transforming the Rewards for Military Service, Monograph presented as part of the MIT Security Studies Program (Cambridge, MA: Massachusetts Institute of Technology, September 2005), 16-17. 